\title{
Investigating a Syndromic Surveillance Signal with Complimentary Data Systems
}

\author{
Hilary B. Parton*, Robert Mathes, Jasmine Abdelnabi, Lisa Alleyne, Andrea Econome, \\ Robert Fitzhenry, Kristen Forney, Megan Halbrook, Stephanie Ngai and Don Weiss
}

Disease Control, NYC Department of Health and Mental Hygiene, Queens, NY, USA

\section{Objective}

To investigate a communicable disease syndromic surveillance signal using multiple data sources.

\section{Introduction}

From June 4-8, 2015, the New York City (NYC) syndromic surveillance system detected five one-day citywide signals in sales of over-the-counter (OTC) antidiarrheal medications using the CUSUM method with a 56-day moving baseline. The OTC system monitors sales of two classes of antidiarrheal medications, products with loperamide or bismuth, from two NYC pharmacy chains. To determine if this increase reflected a concerning cluster of diarrheal illness, we examined multiple communicable disease surveillance data systems.

\section{Methods}

We evaluated the OTC sales data using emergency department chief complaint, school nurse visits, enteric reportable diseases, nosocomial reports, clinical laboratory, water quality, and social media (Table) for 30 days prior to the first signal through one week following the last signal (May 12-June 15).

\section{Results}

We compared weekly counts of antidiarrheal sales during this period for 2014 and 2015. Bismuth sales were slightly higher in June 2015. Loperamide sales were similar between the two years. Promotional sales for both classes of medications were identified before and during the signals.

We observed no temporal or spatial diarrheal signals in our ED system during this period. The ratio of diarrheal to all ED visits decreased, suggesting declining diarrheal illness. A diarrheal signal on June 1 was observed in the school nurse system, but there were no specific increases by grade or neighborhood.

Weekly trend analyses of giardiasis, cryptosporidiosis, salmonellosis, and shigellosis identified five spatial and one borough level signal for giardiasis. The magnitude and location of the signals did not correlate with the OTC sales increase. Campylobacteriosis diagnoses increased in mid-May and early June but this was consistent with seasonal trends. A signal in clinical laboratory submissions was identified on June 10 but volume was not unusual and the baseline was low. No gastrointestinal illness outbreaks were reported through the NORA or sentinel nursing home systems.

Findings from DEP identified one coliform positive, E. coli negative event at a station on June 8. Routine pathogen monitoring for giardia and cryptosporidium showed no abnormal findings, and screening for viruses was negative.

Water quality complaints were within the expected range, and there was no increase in mentions of gastrointestinal illness on social media. Google Trends for gastrointestinal illness did not appear to increase compared with the previous year.

\section{Conclusions}

There were five one-day signals indicative of possible diarrheal illness from our syndromic systems over a five day period in early
June 2015. After further investigation of syndromic and other systems, findings possibly reflected sales promotions but did not suggest increased diarrheal illness in NYC. Using multiple complementary systems can provide useful situational awareness when investigating disease signals.

Data Sources

\begin{tabular}{|c|c|c|}
\hline ata System & Contributors & Detection Criteria \\
\hline OTC pharmacy & $\begin{array}{l}2 \text { NYC pharmacy } \\
\text { chains }\end{array}$ & $\begin{array}{c}\text { Sale of antidiarrheal products (bismuth or loperamide), } \\
\text { or child electrolyte solution; Direct calls to chains } \\
\text { internet searches to identify sales promotions for } \\
\text { antidiarrheal products }\end{array}$ \\
\hline Emergency department & 51 NYC hospitals & $\begin{array}{l}\text { Chief complaint mention of diarrhea or ICD-9 code } \\
787.81\end{array}$ \\
\hline School nurse & & ache or diarrhea \\
\hline Reportable disease & $\begin{array}{l}\text { NYC healthcare } \\
\text { providers and } \\
\text { laboratories }\end{array}$ & $\begin{array}{c}\text { Report of giardiasis, cryptosporidiosis, salmonellosis, } \\
\text { shigellosis, campylobacteriosis; Sentinel reporting } \\
\text { system }\end{array}$ \\
\hline $\begin{array}{c}\text { Nosocomial Reports } \\
\text { (NORA)/sentinel nursing } \\
\text { homes }\end{array}$ & $\begin{array}{l}\text { NYS Article } 28 \\
\text { reporting system }\end{array}$ & $\begin{array}{l}\text { Report of gastrointestinal illness outbreak from } \\
\text { hospitals and nursing homes }\end{array}$ \\
\hline $\begin{array}{c}\text { Clinical laboratory } \\
\text { submissions }\end{array}$ & NYC laboratories & Stool submission for culture and sensitivity \\
\hline Water quality indicators & $\begin{array}{l}\text { Department of } \\
\text { Environmental } \\
\text { Protection }\end{array}$ & $\begin{array}{l}\text { Pathogen monitoring report for giardia or } \\
\text { cryptosporidium; coliform event; boil water alert; } \\
\text { distribution system water chemistry sample for } \\
\text { turbidity and residual chlorine }\end{array}$ \\
\hline Water quality complaints & 311 calls & $\begin{array}{c}\text { Complaint for dirty water, issues with quality/taste, and } \\
\text { color or water access/supply }\end{array}$ \\
\hline Social media & $\begin{array}{l}\text { Twitter, blogs, } \\
\text { internet posts; } \\
\text { Google Trends }\end{array}$ & $\begin{array}{c}\text { Mention of key words (diarrhea, loperamide, Imodium, } \\
\text { water quality); Internet result from key word search } \\
\text { (diarrhea, loperamide, Imodium, antidiarrheal) }\end{array}$ \\
\hline
\end{tabular}

Keywords

Syndromic; Signal; Investigation

*Hilary B. Parton

E-mail: hparton@health.nyc.gov 